\title{
Formation and aging of secondary organic aerosol from toluene: changes in chemical composition, volatility, and hygroscopicity
}

\author{
L. Hildebrandt Ruiz ${ }^{1,2}$, A. L. Paciga ${ }^{2, a}$, K. M. Cerully ${ }^{3, b}$, A. Nenes ${ }^{3}$, N. M. Donahue ${ }^{2}$, and S. N. Pandis ${ }^{2,4}$ \\ ${ }^{1}$ The University of Texas at Austin, Austin, Texas, USA \\ ${ }^{2}$ Carnegie Mellon University, Pittsburgh, Pennsylvania, USA \\ ${ }^{3}$ Georgia Institute of Technology, Atlanta, Georgia, USA \\ ${ }^{4}$ University of Patras, Patras, Greece \\ a now at: Phillips66 ${ }^{\circledR}$, Bartlesville, Oklahoma, USA \\ b now at: TSI, Inc., Shoreview, Minnesota, USA \\ Correspondence to: L. Hildebrandt Ruiz (lhr@che.utexas.edu)
}

Received: 3 November 2014 - Published in Atmos. Chem. Phys. Discuss.: 12 December 2014

Revised: 5 June 2015 - Accepted: 5 July 2015 - Published: 24 July 2015

\begin{abstract}
Secondary organic aerosol (SOA) is transformed after its initial formation, but this chemical aging of SOA is poorly understood. Experiments were conducted in the Carnegie Mellon environmental chamber to form secondary organic aerosol (SOA) from the photo-oxidation of toluene and other small aromatic volatile organic compounds (VOCs) in the presence of $\mathrm{NO}_{x}$ under different oxidizing conditions. The effects of the oxidizing condition on organic aerosol (OA) composition, mass yield, volatility, and hygroscopicity were explored. Higher exposure to the hydroxyl radical resulted in different OA composition, average carbon oxidation state $\left(\mathrm{OS}_{\mathrm{c}}\right)$, and mass yield. The $\mathrm{OA}$ oxidation state generally increased during photo-oxidation, and the final $\mathrm{OA} \mathrm{OS}_{\mathrm{c}}$ ranged from -0.29 to 0.16 in the performed experiments. The volatility of OA formed in these different experiments varied by as much as a factor of 30 , demonstrating that the OA formed under different oxidizing conditions can have a significantly different saturation concentration. There was no clear correlation between hygroscopicity and oxidation state for this relatively hygroscopic SOA.
\end{abstract}

\section{Introduction}

Secondary organic aerosol (SOA) is produced when gasphase precursors are oxidized, forming lower volatility products that partition to the condensed phase. As SOA is estimated to account for approximately $70 \%$ of total aerosol or- ganic carbon mass (Hallquist et al., 2009), the influence of SOA on aerosol composition and related properties is important and complex (Donahue et al., 2009; Kanakidou et al., 2005; Kroll and Seinfeld, 2008). Using measurements in urban, suburban, and remote sites, Zhang et al. (2007) showed that as aerosol ages in the atmosphere, it reaches a highly oxidized state and no longer resembles either fresh primary or secondary aerosol.

Although it is clear that the oxidation of gas-phase compounds and continued oxidation of particle-phase compounds play an important role in SOA production and transformation, the underlying chemistry and thermodynamics are poorly understood. Without the correct representation of SOA production and evolution mechanisms, modeling attempts often lead to underestimations of ambient mass loadings (Heald et al., 2005; Volkamer et al., 2006). The large uncertainty in SOA concentrations predicted by chemical transport models (CTMs) demonstrates the need for experimental data on the multi-generation oxidation reactions or "aging" that lead to changes in mass loadings and physicochemical properties of SOA. Several computational studies have highlighted the importance of not only incorporating extended chemical mechanisms but obtaining corresponding relationships between chemical aging and physiochemical properties of the SOA, such as its volatility, in atmospherically relevant systems (Cappa and Wilson, 2012; Shrivastava et al., 2013)

Considering current "state-of-the-science" aerosol analysis techniques, identifying the plethora of SOA components 
and their individual volatilities is not possible. A unified framework to evaluate complex systems in field or laboratory studies and to track changes in volatility as a function of physicochemical processing is the 2-D-volatility basis set (2D-VBS). It uses coordinates of volatility in terms of effective saturation concentration, $\mathrm{C}^{*}$, and oxidation state of carbon, $\mathrm{OS}_{\mathrm{c}}$ (or the oxygen to carbon ratio, $\mathrm{O}: \mathrm{C}$ ) to provide a space suitable for the description of the chemical transformations and phase partitioning of SOA (Donahue et al., 2012). Chemical species are lumped by $\mathrm{C}^{*}$ and $\mathrm{OS}_{\mathrm{c}}$ in discretized bins.

The relationship between organic aerosol (OA) hygroscopicity and extent of oxidation, indicated by $\mathrm{O}: \mathrm{C}$, has been the focus of a number of laboratory and field studies (Alfarra et al., 2013; Chang et al., 2010; Frosch et al., 2011; Jimenez et al., 2009; Lathem et al., 2013; Massoli et al., 2010). While OA hygroscopicity often increases with $\mathrm{O}: \mathrm{C}$, some other studies have found weak or no correlation between the two properties (Alfarra et al., 2013; Frosch et al., 2011; Lathem et al., 2013; Massoli et al., 2010). It has been shown that $\mathrm{OS}_{\mathrm{c}}$ is likely a better indicator of aerosol oxidation than $\mathrm{O}: \mathrm{C}$ as the latter can be affected by non-oxidative processes such as hydration and dehydration while $\mathrm{OS}_{\mathrm{c}}$ increases continually with oxidation (Canagaratna et al., 2015; Kroll et al., 2009, 2011); thus, O : C may not be as well correlated with observed hygroscopicity.

The organic aerosol $\mathrm{O}: \mathrm{C}$ has been proposed to be linked with its volatility in addition to its hygroscopicity (Jimenez et al., 2009), and a few chamber studies have investigated the link among all three properties (Poulain et al., 2010; Tritscher et al., 2011). The conventional view is that the most volatile components should be the least hygroscopic; however, several studies have observed the opposite behavior (Asa-Awuku et al., 2009; Cerully et al., 2014; Meyer et al., 2009; Poulain et al., 2010). Tritscher et al. (2011) found that hygroscopicity and $\mathrm{O}: \mathrm{C}$ remained constant with decreased volatility for $\alpha$-pinene SOA during aging by $\mathrm{OH}$ radicals.

We investigated the relationship between oxidation, volatility and hygroscopicity of SOA formed from the photooxidation of toluene (methylbenzene) and other small aromatic volatile organic compounds (VOCs) under a variety of oxidation conditions. Small aromatics are important anthropogenic SOA precursors (Pandis et al., 1992; Vutukuru et al., 2006), and toluene serves as a model system to study the formation of SOA from these compounds. A main objective of our work is to connect the extent of oxidation and the changes in volatility of these experiments within the 2-D-VBS framework.

\section{Materials and methods}

\subsection{Environmental chamber experiments}

Organic aerosol was formed from the photo-oxidation of toluene and other small aromatic VOCs in the Carnegie Mellon Center for Atmospheric Particle Studies (CAPS) environmental chamber. The basic sequence of the experiments was to fill the chamber with clean air, inject the VOC and nitrous acid (HONO), and turn on the UV lights to start formation of $\mathrm{OH}$ (from the photolysis of HONO), which oxidizes the VOC and forms secondary organic aerosol (SOA). The number of UV lights used, the initial VOC concentrations, and the number of HONO injections was varied between experiments in order to create different oxidizing environments, as summarized in Table 1. The amount of SOA formed, the SOA oxidation state, its volatility, and its hygroscopicity were measured, as explained in more detail below.

Nitrous acid was produced immediately before injection by drop-wise addition of $12 \mathrm{~mL} 0.1 \mathrm{M}$ sodium nitrite solution to $24 \mathrm{~mL} 0.05 \mathrm{M}$ sulfuric acid solution. Ammonium sulfate $\left(\left(\mathrm{NH}_{4}\right)_{2} \mathrm{SO}_{4}\right.$, Sigma Aldrich, $\left.99.99 \%\right)$ seed particles were used in some experiments (Table 1) to provide surface area onto which organics would condense as SOA. In the unseeded experiments, nucleation of the organic vapors was observed. With the exception of Experiment 7 (Table 1), isotopically labeled toluene was used $\left({ }^{13} \mathrm{C}\right.$-toluene, Cambridge Isotope Laboratories, 99\%) as in a previous study (Hildebrandt et al., 2011). All six ring carbons in the labeled toluene are ${ }^{13} \mathrm{C}$-substituted, leaving the methyl carbon unsubstituted. In two experiments (Expts. 6 and 8) other small aromatic compounds were injected in addition to toluene as detailed in Table 1 in order to test whether these VOCs behave similarly as toluene. Concentrations of the VOCs were monitored using a proton-transfer reaction mass spectrometer (PTR-MS, Ionicon Analytik GmbH) when available. PTR-MS measurements were corrected for ion-source intensity and humidity as suggested by de Gouw et al. (2003). The sensitivity of the PTR-MS to the VOCs was measured before each experiment using a calibration gas mixture.

Figure 1 illustrates the experimental setup. Particle number and volume of the chamber aerosol were measured using a scanning mobility particle sizer (SMPS), comprised of a TSI model 3080 classifier and a TSI model 3772 condensation particle counter (CPC). Particle mass and chemical composition were measured using a high-resolution time-offlight aerosol mass spectrometer (AMS) from Aerodyne, Inc. (DeCarlo et al., 2006). The AMS has two ion optical modes named by the shape of the ion flight paths: a single-reflection mode (V mode) with a shorter flight path and hence higher sensitivity but lower resolution, and a double-reflection mode (W mode) with longer flight path and hence higher resolution but lower sensitivity. In this study the AMS was operated according to common protocol with the vaporizer temperature at $600^{\circ} \mathrm{C}$, alternating between $\mathrm{V}$ and $\mathrm{W}$ modes to collect 
Table 1. Experimental conditions.

\begin{tabular}{|c|c|c|c|c|c|c|}
\hline $\begin{array}{r}\text { Expt. } \\
\#\end{array}$ & Seeds ${ }^{a}$ & $\begin{array}{l}{[\text { Toluene }]_{0}^{\mathrm{b}}} \\
(\mathrm{ppb})\end{array}$ & $\begin{array}{l}{[\text { Toluene }]_{\mathrm{f}}^{\mathrm{c}}} \\
(\mathrm{ppb})\end{array}$ & $\begin{array}{l}\text { HONO } \\
\text { injections }\end{array}$ & $\begin{array}{l}\text { Lights } \\
(\%)\end{array}$ & $\begin{array}{l}{[\mathrm{OH}] \text { exposure }^{\mathrm{d}}} \\
\left(\mathrm{cm}^{-3} \mathrm{~s}\right)\end{array}$ \\
\hline 1 & Yes & $\sim 300$ & NA & 1 & 33 & NA \\
\hline 2 & No & $\sim 200$ & NA & $1+1$ & 100 & NA \\
\hline 3 & Yes & $\sim 300$ & NA & $1+1$ & 100 & NA \\
\hline 4 & No & $\sim 200$ & NA & 2 & 100 & NA \\
\hline 5 & Yes & $\sim 100$ & NA & $2+1$ & 100 & NA \\
\hline 6 & No & $\sim 100^{\mathrm{e}}$ & NA & 2 & 100 & NA \\
\hline 7 & Yes & 1320 & 1130 & 1 & 33 & $3.1 \times 10^{10}$ \\
\hline 8 & Yes & $91^{\mathrm{g}}$ & $51^{\mathrm{h}}$ & 1 & 100 & $10 \times 10^{10}$ \\
\hline 9 & Yes & 115 & 28 & $3+3$ & 100 & $24 \times 10^{10}$ \\
\hline
\end{tabular}

a $\left(\mathrm{NH}_{4}\right)_{2} \mathrm{SO}_{4}$ seed particles were used in some experiments. ${ }^{\mathrm{b}}$ Initial toluene concentrations estimated based on volume of VOC injected for Expts. 1-6 and measured by PTR-MS for Expts. 7-9. ${ }^{\mathrm{c}}$ Final toluene concentration after $\mathrm{OH}$ exposure. ${ }^{\mathrm{d}}$ Total $\mathrm{OH}$ exposure over the course of the experiment, estimated from exponential fits to the decay of toluene. Data not available for experiments 1-6 due to lack of PTR-MS data. ${ }^{\mathrm{e}} 5 \mu \mathrm{L}$ of benzene, o-xylene, and 1,2,4-trimethylbenzene also injected. ${ }^{\mathrm{g}} 16 \mathrm{ppb}$ ethylbenzene, $12 \mathrm{ppb}$ benzene, and $23 \mathrm{ppb}$

1,2,4-trimethylbenzene also injected. ${ }^{\mathrm{h}}$ Final concentrations of ethylbenzene, benzene, and 1,2,4-trimethylbenzene: 9,7 , and $13 \mathrm{ppb}$, respectively.

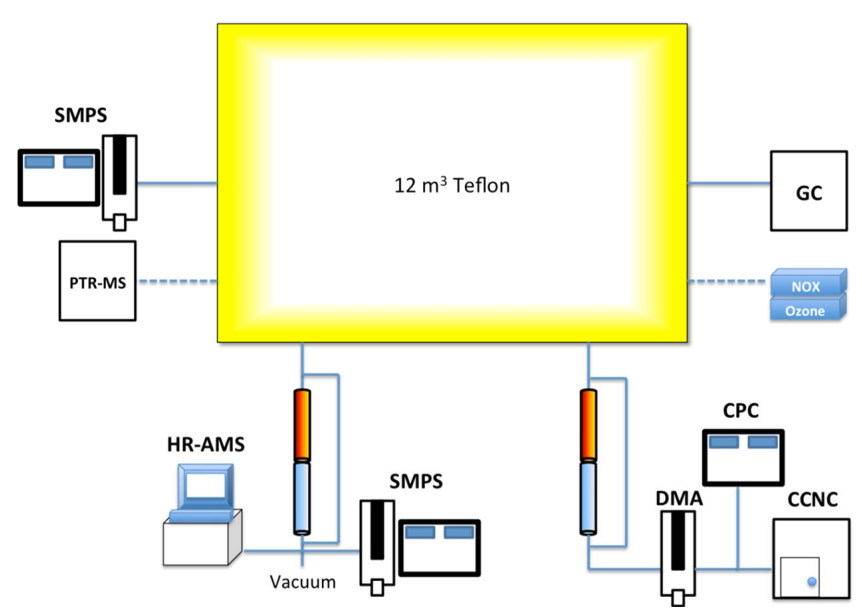

Figure 1. Schematic of experimental setup. Dotted lines indicate that the equipment was used in selected experiments.

mass spectra, and collecting particle time-of-flight (pToF) measurements in $\mathrm{V}$ mode.

Air from the chamber was split into two separate streams for analysis of OA concentrations and properties. In the first stream, OA volatility was probed using a thermodenuder (TD) system, similar to the system used in Lee et al. (2010). Aerosol was passed alternately through the TD, heated to a predefined temperature, or a bypass line and then to the SMPS and the AMS for measurements of the particle size distributions and chemical composition. Properties of thermally treated OA were determined by comparing the residual aerosol after heating in the TD to the aerosol which was passed through the bypass line. The standard operating sample flow rate for the TD was 1 liter per minute $\left(\mathrm{L} \mathrm{min}^{-1}\right)$, corresponding to a centerline residence time of $\sim 15 \mathrm{~s}$. In the TD followed by the AMS, the flow rate was also sometimes set to $0.6 \mathrm{~L} \mathrm{~min}^{-1}$, corresponding to a centerline residence time of $\sim 25 \mathrm{~s}$, to evaluate the effects of a longer residence time on OA evaporation, though these data were not used for thermally denuded $\mathrm{CCN}$ comparisons.

In the second stream, aerosol was again passed alternately through the TD or bypass line, then size-selected (approximately 100 to $140 \mathrm{~nm}$ ) using a differential mobility analyzer (DMA, TSI model 3080) operated with a sheath to aerosol ratio of $10: 1$. Aerosol flow was then split to a CPC (TSI model 3010) and a cloud condensation nuclei counter (CCNc, Droplet Measurement Technologies). The CCNc was operated in Scanning Flow CCN Analysis (SFCA) mode (Moore et al., 2010), allowing for fast measurements of CCN by scanning the flow rate through the $\mathrm{CCNc}$ column, which measured the OA hygroscopicity. The thermodenuder positioned before the $\mathrm{CCNc}$ operated under the same temperature conditions as the AMS-TD and had a sample flowrate of $1 \mathrm{~L} \mathrm{~min}^{-1}$, which allows for analysis of volatility and hygroscopicity of the complete OA and the thermally denuded OA. Dilution air of $1.1 \mathrm{~L} \mathrm{~min}^{-1}$ was introduced after the DMA before splitting to the $\mathrm{CCNc}$ and $\mathrm{CPC}$. Flow to the $\mathrm{CCNc}$ was held constant at $1.1 \mathrm{~L} \mathrm{~min}^{-1}$ using a laminar flow element, while flow in the $\mathrm{CCNc}$ was linearly ramped between 0.1 and $0.9 \mathrm{~L} \mathrm{~min}^{-1}$ over $60 \mathrm{~s}$. The top to bottom column temperature difference was $6^{\circ} \mathrm{C}$ for all experiments.

\subsection{AMS data analysis}

The AMS data were processed in Igor Pro 6.12 (Wavemetrics, Inc.) using the standard AMS data analysis toolkits "Squirrel" version $1.51 \mathrm{C}$ for unit mass resolution (UMR) analysis and "Pika" version 1.10C for high resolution (HR) 
Table 2. Summary of organic aerosol composition and volatility.

\begin{tabular}{rcccccccc}
\hline $\begin{array}{r}\text { Expt } \\
\#\end{array}$ & $\left(\mathrm{NO}_{+} \mathrm{NO}_{2}\right) / \mathrm{OA}^{\mathrm{a}}$ & $\mathrm{OS}_{\mathrm{c}}^{\mathrm{b}}$ & $\mathrm{O}: \mathrm{C}$ & $\mathrm{NO}^{+} / \mathrm{NO}_{2}^{+\mathrm{c}}$ & $\mathrm{H}_{2} \mathrm{O} /\left(\mathrm{CO}_{2}+{ }^{13} \mathrm{CO}_{2}\right)$ & ${ }^{13} \mathrm{CO} /{ }^{13} \mathrm{CO}_{2}^{\mathrm{c}}$ & $\begin{array}{c}\text { Volatility } \\
\text { reduction }(25 \mathrm{~s})^{\mathrm{e}}\end{array}$ \\
\hline 1 & 0.10 & -0.14 & 0.84 & 8.2 & 1.70 & 1.17 & 3.5 \\
reduction $(15 \mathrm{~s})^{\mathrm{e}}$
\end{tabular}

${ }^{a}$ After first period of "lights on". OA includes $\mathrm{NO}^{+}$and $\mathrm{NO}_{2}^{+} \cdot{ }^{\mathrm{b}}$ After first period of "lights on", $\mathrm{OS}_{\mathrm{c}}$ approximated as $2 \times \mathrm{O}: \mathrm{C}-\mathrm{H}: \mathrm{C}$. ${ }^{\mathrm{c}}$ From linear regressions throughout the experiment (when OA present). ${ }^{\mathrm{d}}$ Not applicable (no isotopically labeled VOC used in Experiment 7 ). ${ }^{\mathrm{e}}$ Volatility reduction estimated for data collected at residence times of 15 and $25 \mathrm{~s}$. Values are calculated relative to Experiment 7 which featured the highest volatility.

analysis. HR analysis was performed using the W-mode data since highest resolution is preferred to distinguish between isotopically labeled and unlabeled ions. The lists of ions integrated in the HR analysis is similar to the list used previously (Hildebrandt et al., 2011). Ion masses were fitted up to an $\mathrm{m} / \mathrm{z}$ ratio of 105; above this the signal was too noisy and/or the mass spectra were too crowded for reliable identification of ion atomic composition. According to the UMR analysis more than $95 \%$ of the organic signal was below $m / z 105$, and the total organic mass was corrected based on this fraction calculated for each experiment (Table S1 in the Supplement).

\subsubsection{Modification of standard fragmentation table}

Several adjustments were made to the standard fragmentation table (Allan et al., 2004) for the analysis of HR and UMR data as explained in detail in the supplementary material; only the most important adjustments are summarized here. First, the fragmentation table was adjusted to account for hydrogen atoms $(\mathrm{m} / \mathrm{z}=1)$ formed in the fragmentation of $\mathrm{H}_{2} \mathrm{O}$ (Canagaratna et al., 2015). Second, the amount of $\mathrm{H}_{2} \mathrm{O}^{+}$attributed to organics was chosen so that the mass of water does not correlate with the mass of organics $(R<0.01)$ as expected for these low relative humidity experiments. The ratios of organic $\mathrm{H}_{2} \mathrm{O}^{+}$to $\left({ }^{13} \mathrm{CO}_{2}^{+}+\mathrm{CO}_{2}^{+}\right)$are provided in Table 2 and ranged from 0.3 to 2.4 , higher than the ratio of 0.225 in the default fragmentation table but consistent with recent calibration experiments (Canagaratna et al., 2015). Third, ions assigned to the nitrate family in the HR analysis $\left(\mathrm{NO}^{+}, \mathrm{NO}_{2}^{+}\right)$were added to the total organic aerosol mass in the HR batch table because they appear to be due to organic nitrates: The ratio of $\mathrm{NO}^{+}$to $\mathrm{NO}_{2}^{+}$measured in these experiments (Table 2) is around 8, much higher than the ratio of 2.4 measured in calibration experiments using ammonium nitrate. Furthermore, no inorganic nitrate was added in these experiments. Nitric acid is expected to form in the gas phase but does not appear to partition appreciably to the par- ticle phase, consistent with its high vapor pressure (Fry et al., 2009). Nitrate fragments were not included in the calculation of $\mathrm{O}: \mathrm{C}$ and $\mathrm{H}: \mathrm{C}$ since elemental analysis examines the oxidation state of the carbon atoms.

\subsubsection{Quantification of organic aerosol production}

Data were corrected for changes in the instrument air beam (AB) over the course of an experiment. The ionization efficiency (IE) for each experiment was adjusted based on the ratio of the $\mathrm{AB}$ during the experiment to the $\mathrm{AB}$ during the ionization efficiency calibration conducted before this set of experiments was started (calibration IE/AB $=4.65 \times 10^{-13}$ ). Additional details on quantification of AMS data are provided in the supplementary material. The AMS collection efficiency (CE) for these data was estimated by matching AMS mass distributions and SMPS volume distributions using the OA density $\left(\rho_{\text {org }}\right)$ and AMS CE as fitting parameters, with the algorithm developed by Kostenidou et al. (2007).

The amount of organic aerosol formed was quantified as the fractional aerosol mass yield (mass of OA formed divided by mass of toluene reacted). The mass of OA formed was corrected for the depositional loss of particles onto the chamber walls and for the condensational loss of organic vapors to wall-deposited particles. The assumption was made that condensation of organic vapors is not slowed by mass-transfer resistances, and that the wall-deposited particles are in equilibrium with the organic vapors in suspension. Therefore, the total (corrected) concentration of OA can be calculated by multiplying the OA/seed ratio by the initial seed concentration, as discussed in more detail in Hildebrandt et al. (2009). This correction does not account for condensation of organic vapors onto the "clean" Teflon walls. While these losses have been shown to occur (e.g., Matsunaga and Ziemann, 2010), quantification of their magnitude is an area of active research and remains challenging.

In all of the experiments described here, the condensation sink after particle formation was approximately $1 \mathrm{~min}^{-1}$, 
while the initial condensation sink to ammonium sulfate seeds in seeded experiments ranged between 0.6 and $1 \mathrm{~min}^{-1}$. The timescale for sulfuric acid vapor wall loss in the Carnegie Mellon chamber is approximately $0.1 \mathrm{~min}^{-1}$, as determined by the chemical ionization mass spectrometer measurement of sulfuric acid loss (V. Hofbauer, personal communication, 2015). Thus, in all of the seeded experiments, condensing vapors encountered the seeds approximately 10 times before encountering the walls, while in nucleation experiments the suspended aerosol population quickly grew to a size where this was also true. Thus, while wall losses of semi-volatile vapors are a source of uncertainty, we have attempted to ensure that vapor-particle interactions at least dominate over vapor-wall interactions. It is therefore reasonable to expect that observed differences between experiments are not driven by interactions with the walls but instead by chemical processing of the organic aerosol.

\subsection{Analysis of organic aerosol volatility}

\subsubsection{Data preparation}

Volatility data were collected for each experiment after the SOA had formed. During some experiments, measurements were also made during the irradiation period (with the UV lights on) to examine the volatility changes during photooxidation. TD data are analyzed in terms of the volume fraction remaining (VFR) or mass fraction remaining (MFR). Using the total organic mass concentration from the AMS, the MFR was calculated by dividing the mass concentration of the denuded OA by the mass concentration of the OA that had passed through the bypass. These data are presented in the form of a thermogram, which shows the MFR as a function of temperature in the TD.

Particle concentrations decline in the smog chamber after SOA formation chemistry ceases due to losses to the chamber walls. This can lead to biases in the estimated MFR when bypass concentrations before or after the TD sampling period are used. A more accurate MFR was obtained by interpolation of the bypass OA concentrations corresponding to the TD sampling times. Each experiment was analyzed individually for a best fit, usually resulting in an exponential decay function. Graphs of the interpolated bypass data are shown in Fig. S2.

Particle losses in the TD were also taken into account. These losses occur due to diffusion (primarily of small particles), sedimentation (primarily of large particles), and thermophoresis; the losses are therefore a function of sample flow rate, temperature, and particle size (Burtscher et al., 2001). To estimate the losses within the TD setup, sizedependent loss functions were developed using $\mathrm{NaCl}$ particles under various TD temperatures and sample flow rates (Lee and Pandis, 2010). The number losses for each TD temperature-residence time combination are calculated by determining the losses over the size distribution measured by
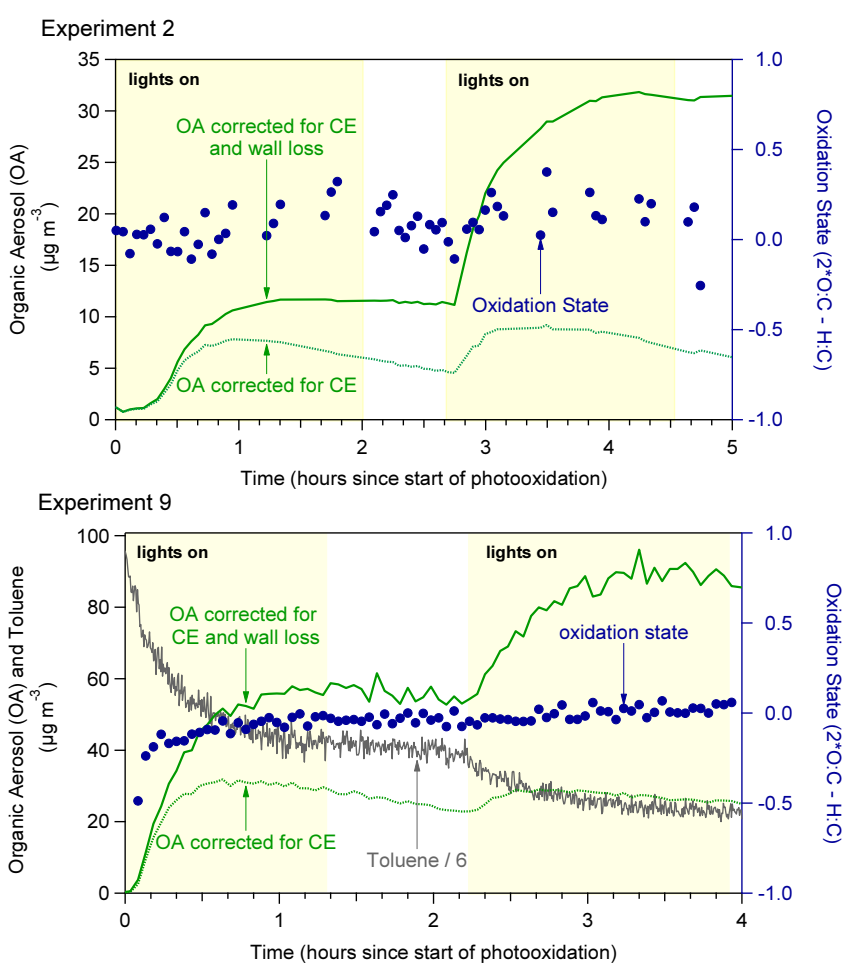

Figure 2. Time series of OA concentration (corrected for CE and corrected for $\mathrm{CE}$ and wall loss) from an unseeded experiment (2, top) and a seeded experiment (9, bottom), both with two photooxidation periods ("lights on") before which HONO was injected. The periods during which the reactor was dark are shown with white background while the periods with UV lights are shaded yellow. Also shown is the OA oxidation state (right axis) and concentrations of toluene during Expt. 9 (toluene concentrations have been divided by 6 on the figure for easier readability).

the SMPS. The number losses for each size bin are then converted to a volume-based correction using the particle diameter of each bin. This correction factor is applied to the calculated MFR values. The organic MFR was calculated from AMS bypass and thermodenuder mass concentrations averaged over 6-9 min for a given TD temperature and residence time. It is assumed that there are no significant changes to composition and volatility over these averaging periods.

\subsubsection{Evaporation model}

Due to the non-equilibrium conditions in the TD, a dynamic mass transfer model developed by Riipinen et al. (2010) was used to estimate the relative volatility of the $\mathrm{OA}$ formed in the experiments outlined in Table 1. Briefly, aerosol evaporation is simulated using experimental inputs including TD temperature, residence time, particle mode diameter, mass concentration, and OA density. This method utilizes the volatility basis set approach (Donahue et al., 2006) to account for the component complexity in the SOA formed. Assuming the particles are in equilibrium with the vapor phase as they en- 


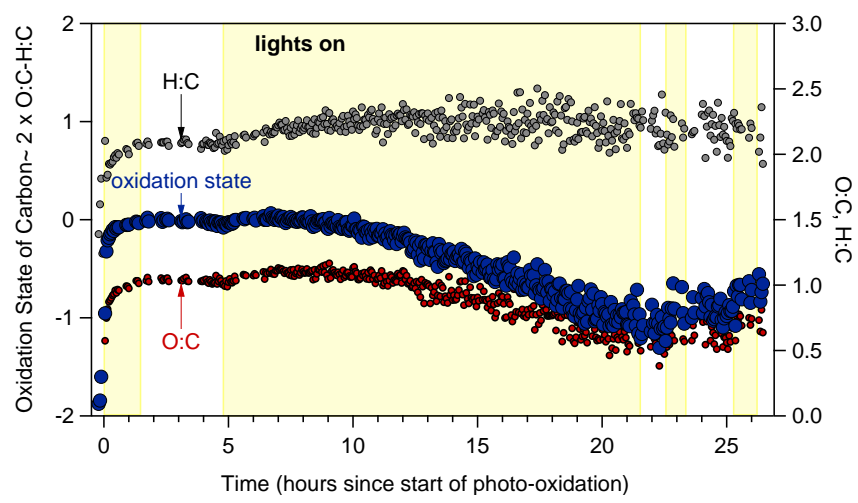

Figure 3. Time series of carbon oxidation state (left axis) and elemental ratios of $\mathrm{O}: \mathrm{C}$ and $\mathrm{H}: \mathrm{C}$ (right axis) for Expt. 3. The periods during which the reactor was dark are shown in with white background while the periods with UV lights are shaded yellow.

ter the TD, the effective saturation concentration is estimated from a least-squares fit to the experimental thermograms. An important caveat to this approach is that physical properties including mass accommodation coefficient and enthalpy of vaporization, which are usually unknown, can substantially affect the volatility estimated (Lee et al., 2010) . The primary goal of these experiments was to observe changes in OA volatility with different levels of oxidation. Thus, relative volatility changes were calculated as described below, thus reducing uncertainties arising from the choice of accommodation coefficient and enthalpy of vaporization.

The volatility of SOA formed in each experiment was determined assuming a fixed volatility distribution shape using four saturation concentrations, $1,10,100$, and $1000 \mathrm{\mu g} \mathrm{m}^{-3}$. During the analysis the saturation concentrations are multiplied by a shifting factor, $s$. This practically shifts the volatility distribution to lower or higher values, assuming that the shape of the distribution does not change. Differences in shifting factors can then be interpreted as differences in the saturation vapor pressure of the OA formed in these experiments: for example, OA with shifting factor 10 is 10 times more volatile than the OA with shifting factor 1 . The volatility distribution used is the fresh toluene SOA distribution estimated by Hildebrandt et al. (2009) for their high $\mathrm{NO}_{x}$ experiments: 0.025 for $C^{*}=1,0.51$ for $C^{*}=10,0.38$ for $C^{*}=100$, and 0.085 for $C^{*}=1000 \mu \mathrm{g} \mathrm{m}^{-3}$ (An organic aerosol concentration of $50 \mu \mathrm{g} \mathrm{m}^{-3}$ was used to convert the product yields reported in Hildebrandt et al., 2009 to normalized mass fractions used here). The shifting factor is estimated for each of the experiments presented here by using the mass transfer model and least-squares fitting to the MFRs. In the last step relative shifting factors are calculated by normalizing them by the shifting factor of the OA formed in Expt. 7, in which SOA had the lowest $\mathrm{OS}_{\mathrm{c}}$. In this way, the relative volatility reduction $(1 / s)$ for each experiment is estimated while accounting for the experiment specifics in-

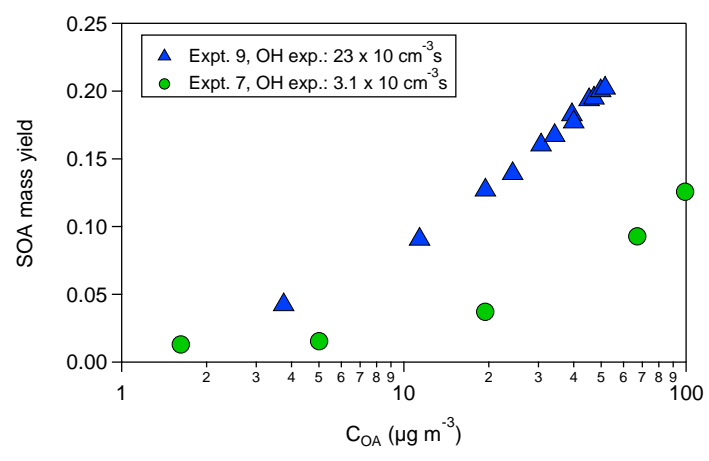

Figure 4. Organic aerosol mass yields for Expts. 7 and 9.

cluding residence time, TD temperature, mass concentration, and particle size. Fixed values are used for the enthalpy of vaporization $\left(80 \mathrm{~kJ} \mathrm{~mol}^{-1}\right)$ and the mass accommodation coefficient (1.0). The sensitivity of results to these choices is discussed in Sect. 3.2.

\subsection{Analysis of $\mathrm{CCN}$ activity}

\subsubsection{CCNc calibration}

The CCNc instrument calibration is used to determine the relationship between instantaneous instrument flow rate and supersaturation as described in Moore et al. (2010). Ammonium sulfate solution is atomized, dried using a silica gel diffusion dryer, charge-neutralized using Po-210, and classified by a DMA. The flow is then introduced into both a CPC and a $\mathrm{CCNc}$. The activation ratio, or the ratio of $\mathrm{CCN}$ to total particles, is then plotted against the instantaneous flow rate to yield data that are fit to a sigmoidal activation ratio function. The critical flow rate, $Q^{*}$, is determined, corresponding to where half of the total particles are activated and to a level of supersaturation, $s^{*}$, equal to the critical supersaturation of the classified aerosol (Sect. 2.4.2). The $Q^{*}$ and $s^{*}$ are determined for a range of aerosol sizes, yielding, for the flow rate range $\left(0.1-0.9 \mathrm{~L} \mathrm{~min}^{-1}\right)$ and temperature gradient $\left(\Delta T=6^{\circ} \mathrm{C}\right)$ in the $\mathrm{CCNc}$ column, supersaturations ranging from approximately 0.1 to $0.5 \%$.

\subsubsection{Calculating aerosol hygroscopicity of size-selected aerosol}

Using the method outlined in Sect. 2.4.1, $s^{*}$ was determined for each flow rate upscan and downscan. All CCNc data subject to poor counting statistics (where the maximum $\mathrm{CCN}$ concentrations were lower than approximately 15 to 20 counts $\mathrm{cm}^{-3}$ ) were excluded from analysis (Moore et al., 2010). The characteristic hygroscopicity parameter, $\kappa$ (Petters and Kreidenweis, 2007), of the monodisperse CCN is then determined by

$\kappa=\frac{4 A^{3}}{27 d_{\mathrm{p}}^{3} s^{* 2}}$, 

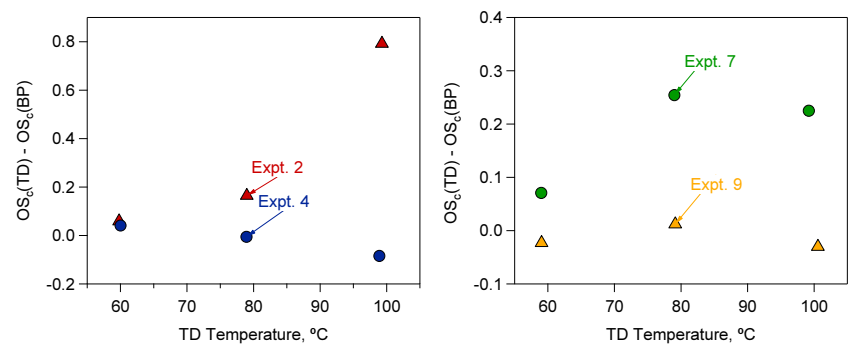

Figure 5. Comparison of the difference in oxidation state of denuded and total OA versus TD temperature for two unseeded experiments ( 2 and 4, left panel) and two seeded experiments ( 7 and 9 , right panel). For OA of intermediate oxidation state (around 0, Expts. 4 and 9), oxidation state of the denuded OA is similar to the oxidation state of the full OA, implying that oxidation state does not correlate significantly with volatility. For OA of higher or lower oxidation state (Expts. 2 and 7, respectively) oxidation state anticorrelates with volatility, shown here as an increase in oxidation state difference with TD temperature.

where $A=\left(4 M_{\mathrm{w}} \sigma_{\mathrm{w}}\right) /\left(R T \rho_{\mathrm{w}}\right) ; M_{\mathrm{w}}, \sigma_{\mathrm{w}}$, and $\rho_{\mathrm{w}}$ are the molar mass, surface tension, and density of water, respectively. $R$ is the universal gas constant, $T$ is CCNc mid-column temperature, and $d_{\mathrm{p}}$ is the dry particle diameter selected by the DMA prior to the CCNc.

\section{Results and discussion}

\subsection{Organic aerosol concentration, composition and mass yield}

Figure 2 shows the time series of OA concentrations and oxidation state for an unseeded experiment (2, top panel) and a seeded experiment ( 9 , bottom panel). The time series of toluene concentrations are also shown for Expt. 9; these data were not available for Expt. 2. There were two photooxidation periods ("lights on") during each experiment, and HONO was injected every time before lights were turned on. During Experiment 2, the OA was alternatively passed through the bypass and the TD throughout the experiment (only the bypass data are shown in Fig. 2). The TD was held at the same temperature during the photo-oxidation periods to observe changes in volatility during this period, and the temperature in the TD was varied during the dark period to obtain a thermogram. During Experiment 9, the OA was passed only through the bypass during photo-oxidation, and it was alternated between bypass and TD (at different temperatures) during the dark period. The OA concentrations increased during the oxidation periods ("lights on") as toluene was oxidized to form SOA. Toluene concentrations decreased by approximately $50 \%$ during the first photooxidation period in Expt. 9 and decreased an additional 20\% during the second photo-oxidation period. Thus, gas-phase toluene is always present in the system and fresh toluene
SOA is expected to form at the same time as the previously formed toluene SOA is aged photochemically.

A moderate increase in the OA oxidation state was observed during the "lights on" period in both experiments. Two competing effects can influence the OA oxidation state: First, according to partitioning theory, species of increasingly higher volatility will partition to the particle phase as the OA loading in the system increases. If oxidation state is anticorrelated with volatility this effect would decrease oxidation state when OA concentration increases. Second, the existing OA can be oxidized further (aged), increasing the OA oxidation state as long as the molecules composing the OA do not fragment. The OA oxidation state of the OA formed increased for several hours in the experiments shown in Fig. 2 and all other experiments conducted as part of this work, suggesting that the aging effect dominated.

In an attempt to produce highly oxidized OA, photooxidation of the OA was continued for over $24 \mathrm{~h}$ during experiments 3 and 5. Figure 3 shows the time series of oxidation state and elemental ratios $(\mathrm{O}: \mathrm{C}$ and $\mathrm{H}: \mathrm{C})$ for Expt. 3 . As before, $\mathrm{HONO}$ was injected before every irradiation period. The OA oxidation state increased during the first few hours of irradiation but significantly decreased after longer irradiation. Plausible explanations for this decrease in oxidation state (which was also observed after long irradiation in Experiment 5) include the condensation of less oxidized vapors, photolysis of OA components and their fragmentation after continued oxidation with $\mathrm{OH}$. Fragmented products may have a high oxidation state but high volatility (due to their smaller size) and evaporate from the OA, decreasing the OA average oxidation state. Photolysis of organic compounds is expected to occur throughout the experiment (e.g., Surratt et al., 2006), but as long as $\mathrm{OH}$ reactions dominate, the oxidation state of the bulk OA increases. Future experiments should aim to isolate $\mathrm{OH}$ from photolysis reactions by, for example, using a dark $\mathrm{OH}$ source. This would help to constrain these effects and eventually represent them in chemical transport models.

Table 2 provides a summary of the OA composition for all experiments investigated here. The observed oxidation state of the OA formed ranged from -0.29 to 0.16 . At least $10 \%$ of the OA mass was due to the sum of $\mathrm{NO}^{+}$and $\mathrm{NO}_{2}^{+}$ions. The observed ratio of $\mathrm{NO}^{+}$to $\mathrm{NO}_{2}^{+}$(Table 2) was between 7.0 and 8.6, much higher than the ratio of 2.4 measured in calibration experiments using ammonium nitrate, suggesting that the $\mathrm{NO}^{+}$and $\mathrm{NO}_{2}^{+}$ions originate from organic nitrogen $(\mathrm{ON})$ compounds. Estimating that the $\mathrm{ON}$ compounds have an average molecular weight of about $200 \mathrm{~g} \mathrm{~mol}^{-1}$, approximately half of the $\mathrm{OA}$ is due to $\mathrm{ON}$. Thus, organic nitrogen compounds are a major constituent in the $\mathrm{OA}$ formed in these high- $\mathrm{NO}_{x}$ photo-oxidation experiments.

In Experiments 6 and 8, other small aromatic VOCs were injected in addition to toluene. The OA formed in these experiments did not stand out in terms of its composition, 


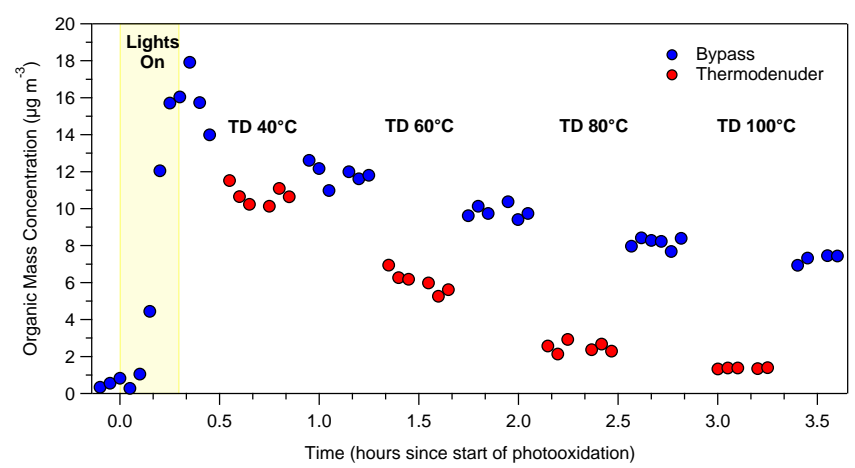

Figure 6. Bypass (blue) and thermodenuder (red) organic mass concentration time series for Expt. 7. The yellow shaded region denotes time when the UV lights were on. Temperatures represent the TD setpoint temperature. The bypass data have not been corrected for losses to the walls of the chamber. The TD measurements have not been corrected for losses in the TD.

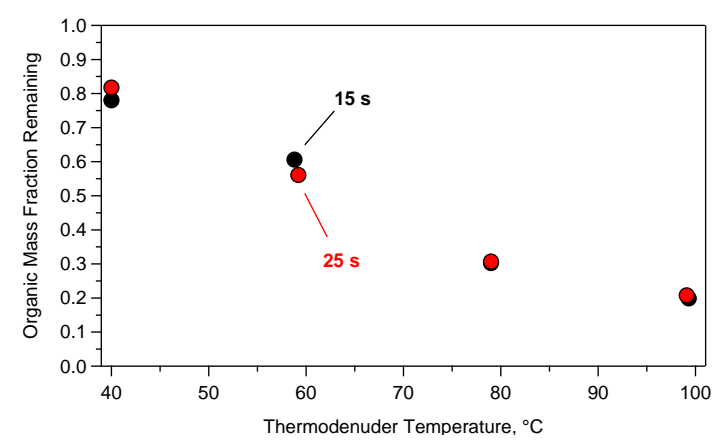

Figure 7. Organic mass fraction remaining as a function of thermodenuder temperature at a residence time of $15 \mathrm{~s}$ (black) and $25 \mathrm{~s}$ (red) for Expt. 7. Thermograms have been corrected for TD losses.

volatility (Sect. 3.3) or hygroscopicity (Sect. 3.4). This suggests that other small aromatic VOCs behave similarly as toluene and that toluene can be used as a model system to study small aromatic VOCs.

\subsection{High and low oxidation experiments - a case study}

This section compares two seeded experiments (number 7 and 9, Table 1) and two unseeded experiments (number 2 and 4). The aim in the design of these experiments was to create different photochemical conditions. Therefore, fewer HONO injections were performed, more toluene was injected, fewer lights were used (resulting in lower UV intensity), and the irradiation period was shorter in Expt. 7 compared to Expt. 9 (10 min and $3 \mathrm{~h}$, respectively). The decay of toluene, monitored by the PTR-MS, was used to estimate the $\mathrm{OH}$ exposure of the OA during irradiation. Total $\mathrm{OH}$ exposure during Expt. 7 was 7-8 times lower than during Expt. 9. Figure 4 shows the OA mass yields for experiments 7 and 9 as a function of the corrected OA concentration in the system; only the first irradiation period was used for Expt. 9 as uncertainties due

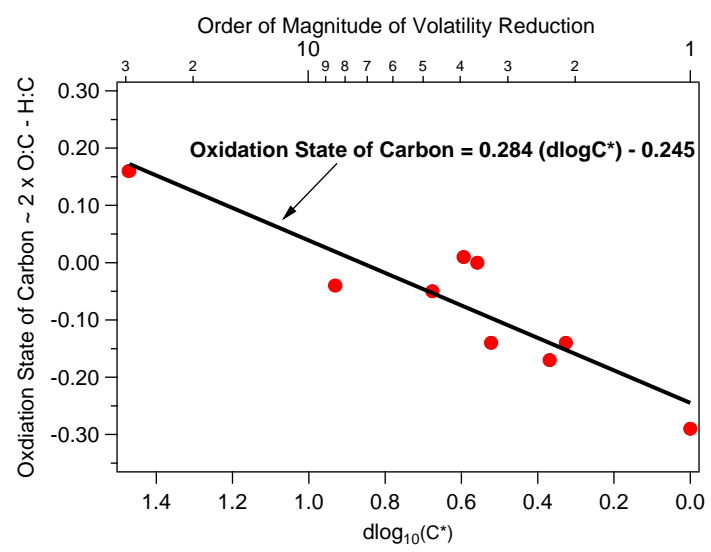

Figure 8. Oxidation state and volatility reduction in terms of change of $\log C^{*}$ for the toluene SOA system. Red circles represent a single experiment and a single best-fit (black) line shows the trend.

to wall losses increase over the course of an experiment. The OA yields are higher for Expt. 9, which exhibited higher $\mathrm{OH}$ exposure. Considering only the first irradiation period, $\mathrm{OH}$ exposure in Expt. 9 was 5 times higher than in Expt. 7. The OA formed in Expt. 9 also exhibited significantly higher oxidation state $(\sim 0$, Table 2$)$ than the OA formed in Expt. 7 $(\sim-0.3)$, and its volatility was approximately a factor of 7 lower than the volatility of the OA formed in Expt. 7 (Table 2).

Previous work has suggested that higher $\mathrm{OH}$ exposures help to reduce wall losses (Kroll et al., 2007); therefore, different oxidizing conditions could result in different wall-loss rates of semi-volatile vapors. As mentioned in Sect. 2.2.2 above, the changes observed in these experiments seem to be driven by chemical processes, not by the interactions with chamber walls. Thus, the higher oxidation state and lower volatility observed during Expt. 9 were likely a result of higher $\mathrm{OH}$ exposure.

The OA mass yields shown in Fig. 4 are lower than high$\mathrm{NO}_{x}$ OA mass yield measured in our previous study (Hildebrandt et al., 2009), likely due to different initial and oxidizing conditions. In the previous study the source of $\mathrm{OH}$ and $\mathrm{NO}_{x}$ was $\mathrm{HOOH}$ and $\mathrm{NO}$, and all $\mathrm{NO}$ converted to $\mathrm{NO}_{2}$ within a few minutes of the start of photo-oxidation. In the present study the source of $\mathrm{OH}$ and $\mathrm{NO}_{x}$ was $\mathrm{HONO}$, and both $\mathrm{NO}$ and $\mathrm{NO}_{2}$ were present throughout the experiments. Gas-phase chemistry is primarily affected by the level of NO, not total $\mathrm{NO}_{x}$, and lower OA mass yields are expected under high $\mathrm{NO}$, high $\mathrm{NO}_{x}$ conditions (present study) compared to high $\mathrm{NO}_{x}$, low $\mathrm{NO}$ conditions (Hildebrandt et al., 2009).

Differences in the OA composition are also apparent when comparing the total OA to the denuded OA from these two experiments. Figure 5 (right panel) shows the difference in oxidation state of the denuded and the total OA at the different TD temperatures for Expt. 7 and 9. For the less oxidized, more volatile OA formed in Expt. 7, the oxidation state of 
the denuded OA is higher than the oxidation state of the total OA, as expected when volatility correlates with oxidation state. The difference is larger at the higher TD temperatures when a larger fraction of the total OA has evaporated. However, for the more oxidized, less volatile OA formed in Expt. 9 , the denuded OA has essentially the same oxidation state as the total OA at all TD temperatures. This is consistent with the OA being composed of molecules that have a similar oxidation state but different chain length, resulting in different volatilities. A similar observation was made when sampling highly oxygenated OA during ambient measurements in Finokalia, Greece, where the fraction of OA due to fragments of $m / z 44$ was not significantly different for denuded and total OA (Hildebrandt et al., 2010).

A similar comparison can be made for two non-seeded experiments (number 2 and 4), which resulted in OA of different oxidation state and volatility (Table 2). Data from the PTR-MS were not available for this experiment; hence, $\mathrm{OH}$ exposure could not be estimated and OA mass yields could not be calculated, but it is likely that higher $\mathrm{OH}$ concentrations as well as lower OA concentrations in Expt. 2 resulted in the more oxidized, less volatile OA. The OA formed in Expt. 4 had similar oxidation state as the OA formed in Expt. 9 mentioned above $(\sim 0)$. The OA formed in Expt. 2 had the highest oxidation state of all OA analyzed here $(\sim 0.16)$, and its volatility was about a factor of 7 lower than the volatility of the OA formed in Expt. 4. The left panel of Fig. 5 shows the difference in oxidation state (denuded vs. total) as a function of TD temperature for Expts. 2 and 4. The OA formed in Expt. 4 exhibits similar behavior as the OA formed in Expt. 9 , with very little difference between the oxidation state of denuded and total OA. The OA in Expt. 2 shows a higher oxidation state for denuded OA than for non-denuded OA. Thus, it appears that for OA of lower and higher bulk oxidation state, the oxidation state anti-correlates with volatility, shown here as a higher oxidation state of the denuded OA. For OA of intermediate oxidation state (around zero), the volatility of the OA does not correlate significantly with bulk oxidation state. The volatility and oxidation state of OA formed in all experiments is analyzed further below.

\subsection{Volatility}

Figure 6 shows mass concentration time series measured during Experiment 7 including both the bypass and TD measurements. This experiment produced the least oxidized and most volatile SOA and serves as the baseline for comparison of OA volatility in the other experiments. HONO was injected into the chamber and, at $t=0$, the UV lights in the chamber (30\% of them) were turned on. The hydroxyl radical formed during the HONO photolysis began to react with toluene and the organic mass concentration increased due to the formation of SOA. The lights remained on for approximately $15 \mathrm{~min}$ and at that point the HONO photolysis was stopped by turning off the UV lights. The AMS then alter- nated between the bypass line and thermodenuder (operating at different temperatures and residence times) to obtain the thermogram shown in Fig. 7. Half of the organic aerosol mass evaporated at $70^{\circ} \mathrm{C}\left(T_{50}\right.$ temperature $)$. For this and all other experiments, the MFR was nearly the same after 15 and $25 \mathrm{~s}$ residence time in the thermodenuder.

The 15 and 25 s residence time data sets were independently modeled, resulting in two estimates of volatility reduction for each experiment. These were quite similar (Table 2) for all cases, suggesting that these measurements are consistent with the choice of a unity accommodation coefficient. The estimated relative volatility reductions relative to Experiment 7 for all experiments are presented in Table 2, and the experiment-specific model inputs (OA loading, particle mode diameter, and OA density) are presented in Table S2. Volatility was lower in other experiments by as much as a factor of 30 , demonstrating that the OA formed under different oxidation conditions can have significantly different vapor pressure. A comparison of the modeled versus the measured MFRs is shown in Fig. S3.

Sensitivity runs were performed in order to examine the effects of the accommodation coefficient and enthalpy of vaporization parameters. In summary, the analysis revealed that changing the mass accommodation coefficients between 0.01, 0.1, and 1 for Expts. 7 and 9, which exhibited quite different experimental conditions, changes neither the relative volatility reduction nor the goodness of fit (represented by the sum of squared residuals, SSR) by more than $15 \%$. In addition, better least-squares fits are obtained for enthalpy of vaporization of $80 \mathrm{~kJ} \mathrm{~mol}^{-1}$ (average SSR for all nine experiments, $\mathrm{SSR}_{\mathrm{avg}}=0.04$ ) than for enthalpy of vaporizations of 20 or $120 \mathrm{~kJ} \mathrm{~mol}^{-1}\left(\mathrm{SSR}_{\mathrm{avg}}=0.11\right.$ and 0.09 , respectively). Changing the enthalpy of vaporization does not change the trends in volatility reduction between experiments. More detailed results of the sensitivity study are presented in the supplementary material.

\section{Dependence of volatility on oxidation state}

Differences in volatility of the toluene SOA in these experiments can be compared to its carbon oxidation state (Fig. 8). The change in volatility is expressed as the logarithm of the volatility reduction. This is consistent with the assumption of a constant volatility distribution shape shifting. Each data point represents a single experiment in terms of volatility reduction or the change in $\log C^{*}$ and the corresponding $\mathrm{OS}_{\mathrm{c}}$. In general, the more oxidized organic aerosol is, the less volatile it is. This is consistent with functionalization reactions decreasing the volatility of the OA as it is oxidized. Using a least-squares fit, a straight line is fit to the data set giving a relation of $\left(\mathrm{OS}_{\mathrm{c}}\right)=0.284\left(\Delta \log _{10} \quad C^{*}\right)-0.245$. This suggests that an increase of the oxidation state by approximately 0.3 units corresponds to a reduction of the average volatility by an order of magnitude for the toluene SOA system examined here. However, as discussed in Sect. 3.2, the 

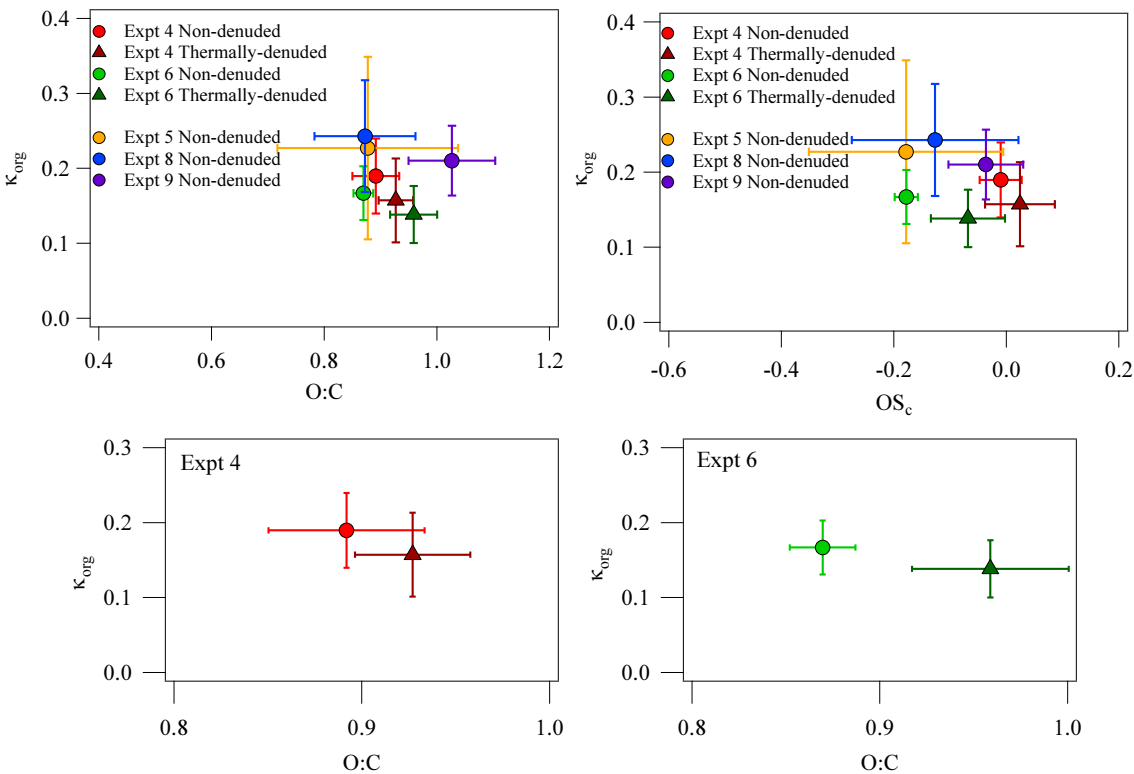

Figure 9. $\kappa_{\text {org }}$ versus $\mathrm{O}: \mathrm{C}$ (top, left) and $\mathrm{OS}_{\mathrm{c}}$ (top, right) for all experiments as listed in Table 1. Also shown are magnified hygroscopicity and $\mathrm{O}: \mathrm{C}$ for unseeded experiments with non-denuded and thermally denuded measurements (bottom). Vertical and horizontal error bars represent the standard deviation in $\kappa_{\mathrm{org}}$ and $\mathrm{O}: \mathrm{C}$ or $\mathrm{OS}_{\mathrm{c}}$, respectively.

volatility of individual species composing the $\mathrm{OA}$ is not always correlated to their oxidation state.

\subsection{Hygroscopicity}

CCNc-derived organic hygroscopicity, $\kappa_{\text {org }}$, expressed as the average hygroscopicity of all measured sizes, versus the bulk $\mathrm{O}: \mathrm{C}$ ratio and $\mathrm{OS}_{\mathrm{c}}$ is shown in Fig. 9 for each experiment where $\mathrm{CCNc}$ data were available. Throughout all experiments, $\kappa_{\text {org }}$ ranges from 0.10 to 0.25 while bulk $\mathrm{O}: \mathrm{C}$ ranges from approximately 0.85 to 1.05 . For each experiment, after the initial period of photo-oxidation, $\kappa_{\text {org }}$ remains fairly constant, as does $\mathrm{O}: \mathrm{C}$. There is no clear correlation between $\kappa_{\text {org }}$ and O:C (Fig. 9, top, left) or between $\kappa_{\text {org }}$ and $\mathrm{OS}_{\mathrm{c}}$ (Fig. 9, top, right) across all experimental conditions. This is counter to the conventional view that oxidative aging of aerosol generally increases its hygroscopicity (Jimenez et al., 2009).

When investigating $\kappa_{\text {org }}$ for Expts. 4 and 6 where both nondenuded and thermally denuded measurements were collected, it appears that thermally denuded aerosol (combined measurements from 60,80 , and $100^{\circ} \mathrm{C}$ ) may show a slight decrease in $\kappa_{\text {org }}$ with increased $\mathrm{O}: \mathrm{C}$ (and $\mathrm{OS}_{\mathrm{c}}$ ) (Fig. 9 bottom). While the change in $\kappa_{\text {org }}$ as well as $\mathrm{O}: \mathrm{C}$ and $\mathrm{OS}_{\mathrm{c}}$ cannot be concluded with confidence due to the relatively large variation in $\kappa_{\text {org }}$, it is possible that this relationship between hygroscopicity and oxidation suggests that there may be another process, aside from bulk oxidation changes, causing changes in the measured hygroscopicity. Sareen et al. (2013) showed that gas-phase compounds such as methylglyoxal can act as surfactants, which depress surface tension and enhance $\mathrm{CCN}$ activity (and hygroscopicity). As methylglyoxal as well as other gas-phase surface-active compounds such as benzaldehyde and glyoxal are known products of toluene oxidation by $\mathrm{OH}$ (Baltaretu et al., 2009), it is likely that gasphase surfactants are present in these experiments. If surfactant films are present on the non-denuded aerosol, enhancing their hygroscopicity, then desorption of the surfactants later upon heating may increase surface tension and depress apparent hygroscopicity. A monolayer of surfactant adsorbed from the gas phase would induce a negligible impact on bulk $\mathrm{O}: \mathrm{C}$ or $\mathrm{OS}_{\mathrm{c}}$. Thus, the volatility of OA would not necessarily correlate with its oxidation state if surfactants are present. Another potential explanation for the lack of a clear correlation between $\kappa_{\mathrm{org}}$ and $\mathrm{OS}_{\mathrm{c}}$ is that the OA composition is dominated by compounds with similar $\mathrm{OS}_{\mathrm{c}}$ but different size (e.g., oligomers), as the size of molecules affects their solubility and therefore their hygroscopicity.

\section{Conclusions}

Photochemical aging clearly influences anthropogenic SOA, and the general trend toward increased SOA mass and reduced volatility is consistent with progressive oxidation driving organic aerosol toward the highly oxidized, low-volatility endpoint observed around the world. There is a strong relationship between exposure to $\mathrm{OH}$ and physicochemical properties for SOA formed from the oxidation of toluene and other small aromatic VOCs. Organic nitrogen compounds are a major constituent in the SOA formed. An experiment with higher $\mathrm{OH}$ exposure showed higher SOA mass yields, more oxidized SOA, and reduced SOA volatility but only 
modest differences in hygroscopicity. Volatility varied by a factor of 30 for different $\mathrm{OH}$ exposure, and a 10-fold decrease in volatility was associated with a 0.3 increase in carbon oxidation state. The SOA was relatively hygroscopic for organic material, with $0.1<\kappa<0.2$ and if anything, a slightly negative relationship between kappa and oxidation state was observed, suggesting a possible role for surfactants or oligomeric compounds. The relationship between hygroscopicity, oxidation state, and volatility may be modulated by gas-phase compounds.

While individual experiments with different $\mathrm{OH}$ exposure showed clear aging effects as different oxidation states and OA volatility, these effects were not evident within every single experiment. This suggests that a complex interplay exists between gas-phase processes, including oxidation reactions that both functionalize and fragment condensable organic species as well as photolysis of some species. The composition, hygroscopicity, and volatility of organic aerosol do not always follow a prescribed relationship, highlighting the need for future laboratory experiments and ambient measurements which evaluate all of these properties.

\section{The Supplement related to this article is available online at doi:10.5194/acp-15-8301-2015-supplement.}

Acknowledgements. This work was supported by the EPA STAR program (grant RD-835405) and the Department of Energy Atmospheric Science Research Program (ASR grant DESC0007075). The high-resolution AMS was purchased with funds from NSF Major Research Instrumentation (CBET0922643) and the Wallace Research Foundation.

Edited by: A. Laskin

\section{References}

Alfarra, M. R., Good, N., Wyche, K. P., Hamilton, J. F., Monks, P. S., Lewis, A. C., and McFiggans, G.: Water uptake is independent of the inferred composition of secondary aerosols derived from multiple biogenic VOCs, Atmos. Chem. Phys., 13, 1176911789, doi:10.5194/acp-13-11769-2013, 2013.

Allan, J. D., Delia, A. E., Coe, H., Bower, K. N., Alfarra, M. R., Jimenez, J. L., Middlebrook, A. M., Drewnick, F., Onasch, T. B., Canagaratna, M. R., Jayne, J. T., and Worsnop, D. R.: A generalised method for the extraction of chemically resolved mass spectra from Aerodyne aerosol mass spectrometer data, J. Aerosol Sci., 35, 909-922, doi:10.1016/j.jaerosci.2004.02.007, 2004

Asa-Awuku, A., Engelhart, G. J., Lee, B. H., Pandis, S. N., and Nenes, A.: Relating CCN activity, volatility, and droplet growth kinetics of $\beta$-caryophyllene secondary organic aerosol, Atmos. Chem. Phys., 9, 795-812, doi:10.5194/acp-9-795-2009, 2009.
Baltaretu, C. O., Lichtman, E. I., Hadler, A. B., and Elrod, M. J.: Primary atmospheric oxidation mechanism for toluene., J. Phys. Chem. A, 113, 221-30, doi:10.1021/jp806841t, 2009.

Burtscher, H., Baltensperger, U., Bukowiecki, N., Cohn, P., Huglin, C., Mohr, M., Matter, U., Nyeki, S., Schmatloch, V., Streit, N., and Weingartner, E.: Separation of volatile and nonvolatile aerosol fractions by thermodesorption: Instrumental development and applications, J. Aerosol Sci., 32, 427-442, doi:10.1016/S0021-8502(00)00089-6, 2001.

Canagaratna, M. R., Jimenez, J. L., Kroll, J. H., Chen, Q., Kessler, S. H., Massoli, P., Hildebrandt Ruiz, L., Fortner, E., Williams, L. R., Wilson, K. R., Surratt, J. D., Donahue, N. M., Jayne, J. T., and Worsnop, D. R.: Elemental ratio measurements of organic compounds using aerosol mass spectrometry: characterization, improved calibration, and implications, Atmos. Chem. Phys., 15, 253-272, doi:10.5194/acp-15-253-2015, 2015.

Cappa, C. D. and Wilson, K. R.: Multi-generation gas-phase oxidation, equilibrium partitioning, and the formation and evolution of secondary organic aerosol, Atmos. Chem. Phys., 12, 9505-9528, doi:10.5194/acp-12-9505-2012, 2012.

Cerully, K. M., Bougiatioti, A., Hite Jr., J. R., Guo, H., Xu, L., Ng, N. L., Weber, R., and Nenes, A.: On the link between hygroscopicity, volatility, and oxidation state of ambient and watersoluble aerosol in the Southeastern United States, Atmos. Chem. Phys. Discuss., 14, 30835-30877, doi:10.5194/acpd-14-308352014, 2014.

Chang, R. Y.-W., Slowik, J. G., Shantz, N. C., Vlasenko, A., Liggio, J., Sjostedt, S. J., Leaitch, W. R., and Abbatt, J. P. D.: The hygroscopicity parameter $(\kappa)$ of ambient organic aerosol at a field site subject to biogenic and anthropogenic influences: relationship to degree of aerosol oxidation, Atmos. Chem. Phys., 10, 5047-5064, doi:10.5194/acp-10-5047-2010, 2010.

DeCarlo, P. F., Kimmel, J. R., Trimborn, A. M., Northway, M. J., Jayne, J. T., Aiken, A. C., Gonin, M., Fuhrer, K., Horvath, T., Docherty, K. S., Worsnop, D. R., and Jimenez, J. L.: Field-Deployable, High-Resolution, Time-of-Flight Aerosol Mass Spectrometer, Anal. Chem., 78, 8281-8289, 2006.

De Gouw, J. A., Goldan, P. D., Warneke, C., Kuster, W. C., Roberts, J. M., Marchewka, M., Bertman, S. B., Pszenny, A. A. P., and Keene, W. C.: Validation of proton transfer reaction-mass spectrometry (PTR-MS) measurements of gas-phase organic compounds in the atmosphere during the New England Air Quality Study (NEAQS) in 2002, J. Geophys. Res., 108, 4682, doi:10.1029/2003JD003863, 2003.

Donahue, N. M., Robinson, A. L., Stanier, C. O., and Pandis, S. N.: Coupled Partitioning, Dilution, and Chemical Aging of Semivolatile Organics, Environ. Sci. Technol., 40, 2635-2643, doi:10.1021/es052297c, 2006.

Donahue, N. M., Robinson, A. L., and Pandis, S. N.: Atmospheric organic particulate matter: From smoke to secondary organic aerosol, Atmos. Environ., 43, 94-106, 2009.

Donahue, N. M., Kroll, J. H., Pandis, S. N., and Robinson, A. L. A two-dimensional volatility basis set - Part 2: Diagnostics of organic-aerosol evolution, Atmos. Chem. Phys., 12, 615-634, doi:10.5194/acp-12-615-2012, 2012.

Frosch, M., Bilde, M., DeCarlo, P. F., Juranyi, Z., Tritscher, T., Dommen, J., Donahue, N. M., Gysel, M., Weingartner, E., and Baltensperger, U.: Relating cloud condensation nuclei activity 
and oxidation level of $\alpha$-pinene secondary organic aerosols, J. Geophys. Res., 116, D22212, doi:10.1029/2011JD016401, 2011.

Fry, J. L., Kiendler-Scharr, A., Rollins, A. W., Wooldridge, P. J., Brown, S. S., Fuchs, H., Dubé, W., Mensah, A., dal Maso, M., Tillmann, R., Dorn, H.-P., Brauers, T., and Cohen, R. C.: Organic nitrate and secondary organic aerosol yield from $\mathrm{NO}_{3}$ oxidation of $\beta$-pinene evaluated using a gas-phase kinetics/aerosol partitioning model, Atmos. Chem. Phys., 9, 14311449, doi:10.5194/acp-9-1431-2009, 2009.

Hallquist, M., Wenger, J. C., Baltensperger, U., Rudich, Y., Simpson, D., Claeys, M., Dommen, J., Donahue, N. M., George, C., Goldstein, A. H., Hamilton, J. F., Herrmann, H., Hoffmann, T., Iinuma, Y., Jang, M., Jenkin, M. E., Jimenez, J. L., Kiendler-Scharr, A., Maenhaut, W., McFiggans, G., Mentel, Th. F., Monod, A., Prévôt, A. S. H., Seinfeld, J. H., Surratt, J. D., Szmigielski, R., and Wildt, J.: The formation, properties and impact of secondary organic aerosol: current and emerging issues, Atmos. Chem. Phys., 9, 5155-5236, doi:10.5194/acp-9-51552009, 2009.

Heald, C. L., Jacob, D. J., Park, R. J., Russell, L. M., Huebert, B. J., Seinfeld, J. H., Liao, H., and Weber, R. J.: A large organic aerosol source in the free troposphere missing from current models, Geophys. Res. Lett., 3, L18809, doi:10.1029/2005GL023831, 2005.

Hildebrandt, L., Donahue, N. M., and Pandis, S. N.: High formation of secondary organic aerosol from the photo-oxidation of toluene, Atmos. Chem. Phys., 9, 2973-2986, doi:10.5194/acp-92973-2009, 2009.

Hildebrandt, L., Kostenidou, E., Mihalopoulos, N., Worsnop, D. R., Donahue, N. M., and Pandis, S. N.: Formation of highly oxygenated organic aerosol in the atmosphere: Insights from the Finokalia Aerosol Measurement Experiments, Geophys. Res. Lett., 37, L23801, doi:10.1029/2010GL045193, 2010.

Hildebrandt, L., Henry, K., Kroll, J. H., Pandis, S. N., and Donahue, N. M.: Evaluating the Mixing of Organic Aerosol Components using High-Resolution Aerosol Mass Spectrometry, Environ. Sci. Technol., 45, 6329-6335, doi:10.1021/es200825g, 2011.

Jimenez, J. L., Canagaratna, M. R., Donahue, N. M., Prevot, A. S. H., Zhang, Q., Kroll, J. H., DeCarlo, P. F., Allan, J. D., Coe, H., Ng, N. L., Aiken, A. C., Docherty, K. S., Ulbrich, I. M., Grieshop, a P., Robinson, A. L., Duplissy, J., Smith, J. D., Wilson, K. R., Lanz, V. a, Hueglin, C., Sun, Y. L., Tian, J., Laaksonen, A., Raatikainen, T., Rautiainen, J., Vaattovaara, P., Ehn, M., Kulmala, M., Tomlinson, J. M., Collins, D. R., Cubison, M. J., Dunlea, E. J., Huffman, J. A., Onasch, T. B., Alfarra, M. R., Williams, P. I., Bower, K., Kondo, Y., Schneider, J., Drewnick, F., Borrmann, S., Weimer, S., Demerjian, K., Salcedo, D., Cottrell, L., Griffin, R., Takami, A., Miyoshi, T., Hatakeyama, S., Shimono, a, Sun, J. Y., Zhang, Y. M., Dzepina, K., Kimmel, J. R., Sueper, D., Jayne, J. T., Herndon, S. C., Trimborn, A. M., Williams, L. R., Wood, E. C., Middlebrook, A. M., Kolb, C. E., Baltensperger, U., and Worsnop, D. R.: Evolution of organic aerosols in the atmosphere., Science, 326, 1525-1529, doi:10.1126/science.1180353, 2009.

Kanakidou, M., Seinfeld, J. H., Pandis, S. N., Barnes, I., Dentener, F. J., Facchini, M. C., Van Dingenen, R., Ervens, B., Nenes, A., Nielsen, C. J., Swietlicki, E., Putaud, J. P., Balkanski, Y., Fuzzi, S., Horth, J., Moortgat, G. K., Winterhalter, R., Myhre, C. E. L., Tsigaridis, K., Vignati, E., Stephanou, E. G., and Wilson,
J.: Organic aerosol and global climate modelling: a review, Atmos. Chem. Phys., 5, 1053-1123, doi:10.5194/acp-5-1053-2005, 2005.

Kostenidou, E., Pathak, R. K., and Pandis, S. N.: An Algorithm for the Calculation of Secondary Organic Aerosol Density Combining AMS and SMPS Data, Aerosol Sci. Technol., 41, 1002-1010, doi:10.1080/02786820701666270, 2007.

Kroll, J. H., Chan, A. W. H., Ng, N. L., Flagan, R. C., and Seinfeld, J. H.: Reactions of Semivolatile Organics and their effects on Secondary Organic Aerosol Formation, Environ. Sci. Technol., 41, 3545-3550, doi:10.1021/es062059x, 2007.

Kroll, J. H. and Seinfeld, J. H.: Chemistry of secondary organic aerosol: Formation and evolution of low-volatility organics in the atmosphere, Atmos. Environ., 42, 3593-3624, doi:10.1016/j.atmosenv.2008.01.003, 2008.

Kroll, J. H., Smith, J. D., Che, D. L., Kessler, S. H., Worsnop, D. R., and Wilson, K. R.: Measurement of fragmentation and functionalization pathways in the heterogeneous oxidation of oxidized organic aerosol, Phys. Chem. Chem. Phys., 11, 8005-8014, 2009.

Kroll, J. H., Donahue, N. M., Jimenez, J. L., Kessler, S. H., Canagaratna, M. R., Wilson, K. R., Altieri, K. E., Mazzoleni, L. R., Wozniak, A. S., Bluhm, H., Mysak, E. R., Smith, J. D., Kolb, C. E., and Worsnop, D. R.: Carbon oxidation state as a metric for describing the chemistry of atmospheric organic aerosol, Nat. Chem., 3, 133-139, doi:10.1038/nchem.948, 2011.

Lathem, T. L., Beyersdorf, A. J., Thornhill, K. L., Winstead, E. L., Cubison, M. J., Hecobian, A., Jimenez, J. L., Weber, R. J., Anderson, B. E., and Nenes, A.: Analysis of CCN activity of Arctic aerosol and Canadian biomass burning during summer 2008, Atmos. Chem. Phys., 13, 2735-2756, doi:10.5194/acp-13-27352013, 2013.

Lee, B.-H. and Pandis, S. N.: Volatility of atmospheric organic aerosol, Carnegie Mellon University, Pittsburgh, 2010.

Lee, B. H., Kostenidou, E., Hildebrandt, L., Riipinen, I., Engelhart, G. J., Mohr, C., DeCarlo, P. F., Mihalopoulos, N., Prevot, A. S. H., Baltensperger, U., and Pandis, S. N.: Measurement of the ambient organic aerosol volatility distribution: application during the Finokalia Aerosol Measurement Experiment (FAME2008), Atmos. Chem. Phys., 10, 12149-12160, doi:10.5194/acp10-12149-2010, 2010.

Massoli, P., Lambe, A. T., Ahern, A. T., Williams, L. R., Ehn, M., Mikkilä, J., Canagaratna, M. R., Brune, W. H., Onasch, T. B., Jayne, J. T., Petäjä, T., Kulmala, M., Laaksonen, A., Kolb, C. E., Davidovits, P., and Worsnop, D. R.: Relationship between aerosol oxidation level and hygroscopic properties of laboratory generated secondary organic aerosol (SOA) particles, Geophys. Res. Lett., 37, L24801, doi:10.1029/2010GL045258, 2010.

Matsunaga, A. and Ziemann, P. J.: Gas-Wall Partitioning of Organic Compounds in a Teflon Film Chamber and Potential Effects on Reaction Product and Aerosol Yield Measurements, Aerosol Sci. Technol., 44, 881-892, doi:10.1080/02786826.2010.501044, 2010.

Meyer, N. K., Duplissy, J., Gysel, M., Metzger, A., Dommen, J., Weingartner, E., Alfarra, M. R., Prevot, A. S. H., Fletcher, C., Good, N., McFiggans, G., Jonsson, Å. M., Hallquist, M., Baltensperger, U., and Ristovski, Z. D.: Analysis of the hygroscopic and volatile properties of ammonium sulphate seeded and unseeded SOA particles, Atmos. Chem. Phys., 9, 721-732, doi:10.5194/acp-9-721-2009, 2009. 
Moore, R. H., Nenes, A., and Medina, J.: Scanning Mobility CCN Analysis - A Method for Fast Measurements of Size-Resolved CCN Distributions and Activation Kinetics, Aerosol Sci. Technol., 44, 861-871, doi:10.1080/02786826.2010.498715, 2010.

Pandis, S. N., Harley, R. A., Cass, G. R., and Seinfeld, J. H.: Secondary Organic Aerosol Formation And Transport, Atmos. Environ. Pt. A, 26, 2269-2282, doi:10.1016/0960-1686(92)90358-R, 1992.

Petters, M. D. and Kreidenweis, S. M.: A single parameter representation of hygroscopic growth and cloud condensation nucleus activity, Atmos. Chem. Phys., 7, 1961-1971, doi:10.5194/acp-71961-2007, 2007.

Poulain, L., Wu, Z., Petters, M. D., Wex, H., Hallbauer, E., Wehner, B., Massling, A., Kreidenweis, S. M., and Stratmann, F.: Towards closing the gap between hygroscopic growth and $\mathrm{CCN}$ activation for secondary organic aerosols - Part 3: Influence of the chemical composition on the hygroscopic properties and volatile fractions of aerosols, Atmos. Chem. Phys., 10, 37753785, doi:10.5194/acp-10-3775-2010, 2010.

Riipinen, I., Pierce, J. R., Donahue, N. M., and Pandis, S. N.: Equilibration time scales of organic aerosol inside thermodenuders: Evaporation kinetics versus thermodynamics, Atmos. Environ., 44, 597-607, doi:10.1016/j.atmosenv.2009.11.022, 2010.

Sareen, N., Schwier, A. N., Lathem, T. L., Nenes, A., and McNeill, V. F.: Surfactants from the gas phase may promote cloud droplet formation., Proc. Natl. Acad. Sci. USA, 110, 2723-2728, doi:10.1073/pnas.1204838110, 2013.

Shrivastava, M. K., Zelenyuk, A., Imre, D., Easter, R. C., Beranek, J., Zaveri, R. A., and Fast, J. D.: Implications of low volatility SOA and gas-phase fragmentation reactions on SOA loadings and their spatial and temporal evolution in the atmosphere, J. Geophys. Res. Atmos., 118, 3328-3342, doi:10.1002/jgrd.50160, 2013.
Surratt, J. D., Murphy, S. M., Kroll, J. H., Ng, N. L., Hildebrandt, L., Sorooshian, A., Szmigielski, R., Vermeylen, R., Maenhaut, W., Claeys, M., Flagan, R. C., and Seinfeld, J. H.: Chemical Composition of Secondary Organic Aerosol Formed from the Photooxidation of Isoprene, J. Phys. Chem. A, 110, 9665-9690, 2006.

Tritscher, T., Dommen, J., DeCarlo, P. F., Gysel, M., Barmet, P. B., Praplan, A. P., Weingartner, E., Prévôt, A. S. H., Riipinen, I., Donahue, N. M., and Baltensperger, U.: Volatility and hygroscopicity of aging secondary organic aerosol in a smog chamber, Atmos. Chem. Phys., 11, 11477-11496, doi:10.5194/acp-1111477-2011, 2011.

Volkamer, R., Jimenez, J. L., San Martini, F., Dzepina, K., Zhang, Q., Salcedo, D., Molina, L. T., Worsnop, D. R., and Molina, M. J.: Secondary organic aerosol formation from anthropogenic air pollution: Rapid and higher than expected, Geophys. Res. Lett., 33, L17811, doi:10.1029/2006GL026899, 2006.

Vutukuru, S., Griffin, R. J., and Dabdub, D.: Simulation and analysis of secondary organic aerosol dynamics in the South Coast Air Basin of California, J. Geophys. Res., 111, D10S12, doi:10.1029/2005JD006139, 2006.

Zhang, Q., Jimenez, J. L., Canagaratna, M. R., Allan, J. D., Coe, H., Ulbrich, I., Alfarra, M. R., Takami, A., Middlebrook, A. M., Sun, Y. L., Dzepina, K., Dunlea, E., Docherty, K., DeCarlo, P. F., Salcedo, D., Onasch, T., Jayne, J. T., Miyoshi, T., Shimono, A., Hatakeyama, S., Takegawa, N., Kondo, Y., Schneider, J., Drewnick, F., Borrmann, S., Weimer, S., Demerjian, K., Williams, P., Bower, K., Bahreini, R., Cottrell, L., Griffin, R. J., Rautiainen, J., Sun, J. Y., Zhang, Y. M., and Worsnop, D. R.: Ubiquity and dominance of oxygenated species in organic aerosols in anthropogenically-influenced Northern Hemisphere midlatitudes, Geophys. Res. Lett., 34, L13801, doi:10.1029/2007g1029979, 2007. 